\title{
HUBUNGAN PERSONAL HYGIENE TERHADAP PENYAKIT DERMATITIS DI PONDOK PESANTREN BABUL KHAER KAB.BULUKUMBA \\ Andi Rezky Avita ${ }^{1}$, Wahyuni Sahani ${ }^{2}$ \\ 1,2Jurusan Kesehatan Lingkungan Poltekkes Kemenkes Makassar andirezkyavita@gmail.com
}

\begin{abstract}
Personal hygiene in Islamic boarding schools is very necessary to avoid skin diseases. Dermatitis is a skin disease caused by bacteria that affects the quality of life, appearance, and comfort of the sufferer so that personal hygiene needs to be applied. The purpose of this study was to determine the relationship of personal hygiene to dermatitis in Babul Khaer Islamic Boarding School in Kabul in 2019. The study design used a cross-sectional design with a sample of 45 people and 9 bedroom rooms. The results of the study that showed the cleanliness of the skin of the hands and nails met the requirements of eight respondents (18\%) and did not fulfill the requirements of 37 respondents (82\%), bathing habits met the requirements as many as 11 respondents (24\%) and did not meet the 34 respondents (76\%), the cleanliness of the bed and bedspread does not meet the requirements of 45 (100\%), the clean water used meets the requirements of nine rooms (100\%), moisture does not meet the requirements of nine rooms (100\%). The variable habits of changing clothes and room temperature of the bedroom based on the results of statistical tests obtained the value of $P=0.01<\alpha=0.05$ and the value of $P=0.02<\alpha=0.05$, which means that there is a significant relationship between the habit of changing clothes and the temperature of the bedroom with Dermatitis. The conclusions obtained were that the personal hygiene habits of changing clothes had a significant relationship with dermatitis and the temperature of the bedroom also had a significant relationship with dermatitis. Advice for students is to improve personal hygiene to avoid some infectious diseases, especially skin diseases (dermatitis).
\end{abstract}

Keywords: Dermatitis, Islamic Boarding Schools, and Personal Hygiene.

\section{ABSTRAK}

Personal hygiene di Pondok Pesantren sangat diperlukan untuk menghindari penyakit kulit. Dermatitis merupakan salah satu penyakit kulit yang disebabkan oleh bakteri yang berpengaruh pada kualitas hidup, penampilan, dan kenyamanan penderitanya sehingga personal hygiene perlu diterapkan. Tujuan penelitian ini adalah untuk mengetahui hubungan personal hygiene terhadap penyakit dermatitis di Pondok Pesantren Babul Khaer Kab.Bulukumba Tahun 2019. Rancangan penelitian menggunakan desain cross sectional dengan jumlah sampel 45 orang dan 9 ruang kamar tidur. Hasil penelitian yang menunjukkan kebersihan kulit tangan dan kuku memenuhi syarat sebanyak delapan responden $(18 \%)$ dan tidak memenuhi syarat 37 responden $(82 \%)$, kebiasaan mandi memenuhi syarat sebanyak 11 responden (24\%) dan tidak memenuhi syarat 34 responden (76\%), kebersihan tempat tidur dan seprei tidak memenuhi syarat 45 $(100 \%)$, air bersih yang digunakan memenuhi syarat sebanyak sembilan kamar (100\%), kelembaban tidak memenuhi syarat sembilan kamar (100\%). Variabel kebiasaan mengganti pakaian dan suhu ruangan kamar tidur berdasarkan hasil uji statistik diperoleh nilai $P=0,01<\alpha=0,05$ dan nilai $P=0,02<\alpha=0,05$ yang berarti bahwa ada hubungan yang bermakna antara kebiasaan mengganti pakaian dan suhu kamar tidur dengan penyakit Dermatitis. Kesimpulan yang didapatkan yaitu personal hygiene kebiasaan mengganti pakaian memiliki hubungan yang signifikan dengan penyakit dermatitis dan Suhu kamar tidur juga memiliki hubungan yang signifikan dengan penyakit dermatitis. Saran untuk santriwati yaitu meningkatkan personal hygiene agar terhindar dari beberapa penyakit menular terutama penyakit kulit (Dermatitis).

\section{Kata Kunci : Dermatitis, Pondok Pesantren, dan Personal Hygiene.}

\section{PENDAHULUAN}

Bulukumba merupakan Kabupaten di ujung selatan Sulawesi Selatan, berjarak kurang lebih 153 km dari ibu kota provinsi Sulawesi Selatan, dengan jumlah penduduk 370.728 jiwa. Jumlah pondok pesantren yang ada di kabupaten Bulukumba yaitu sebanyak 6 pondok pesantren salah satunya adalah pondok pesantren babul khaer. Pondok pesantren mempunyai santri/santriwati yang menepuh pendidikan. Dengan jumlah santri yang cukup banyak sangat diharapkan kondisi lingkungan yang bersih dan sehat, sehingga tidak terjadi penularan penyakit dari santri ke santri ataupun dari lingkungan ke santri itu sendiri.

Salah satu penyakit yang biasa timbul dilingkungan pondok pesantren adalah penyakit kulit yang disebaban oleh bakteri salahsatunya adalah Dermatitis. Secara global dermatitis mempengaruhi sekitar 230 juta orang pada 2010 atau 3,5\% dari populasi dunia. prevalensi nasional kasus dermatitis adalah 6,8\%. (Riskesdas,2007). Angka penyakit dermatitis di Sulawesi selatan cukup tinggi yaitu, 53,2\% (bps, 2015) sedangkan Di Kabupaten Bulukumba penyakit dermatitis termasuk kedalam pola 10 penyakit terbanyak untuk semua golongan umur dengan jumlah 29.096 dengan persentasi sebanyak 12,3\%. (Dinkes,2014)

\section{METODE}

Metode yang digunakan dalam penelitian ini yaitu cross sectional dimana variabel bebas dan terikat diukur secara bersamaan

\section{Desain, tempat dan waktu}

Adapun pelaksanaan penelitian dilakukan 
pada 2 tahap yaitu tahap persiapan, meliputi kegiatan seminar proposal yang dilaksanakan pada Bulan Desember 2018-Januari 2019. Tahap kedua pelaksanaan meliputi pengumpulan data yang kemudian ujian hasil yang dilaksanakan pada bulan april-juni 2019.

\section{Jumlah dan cara pengambilan subjek}

Teknik pengambilan sampel yang digunakan yaitu random sampel. Adapun sampel yang diteliti yaitu sebanyak 45 santri.

Jenis dan Cara Pengumpulan Data (untuk penelitian survei)/Langkah-Langkah Penelitian

\section{Data primer}

Data primer diperoleh melalui wawancara dan observasi pada lingkungan Pondok Pesantren Babul Khaer Kab.Bulukumba

\section{Data sekunder}

Data yang diperoleh dari instansi terkait berupa data jumlah siswa, data penyakit Kulit, sarana dan prasarana sanitasi serta gambaran umum lokasi Pondok Pesantren Babul Khaer Kab.Bulukumba

\section{Pengolahan dan analisis data}

Analisis data ditentukan untuk mengetahui hubungan antara variable bebas dan variable terikat. Selain itu, analisis data dapat digunakan untuk menguji hipotesa penelitian. Dalam penelitian ini menggunakan teknik :

\section{Analisis satu variable (univariate)}

Analisis univarite dilakukan untuk mendeskripsikan variable bebas yaitu : kebersihan kulit tangan dan kuku, kebiasaan mandi, kebiasaan mengganti pakaian, kebersihan tempat tidur dan seprei, air, suhu dan kelembaban dalam bentuk presentase karna skala data yang digunakan berupa ordinal.

\section{Analisis dua variable (bivariate)}

Analisis bivariate dilakukan terhadap dua variable yang diduga berhubungan. Analisis ini menggunakan uji statistic berupa uji chi square guna mengetahui hubungan antara personal hygiene terhadap penyakit dermatitis di Pondok Pesantren Babul Khaer kabupaten Bulukumba.
Adapun hasil dari penelitian ini yaitu :

Hubungan Kebersihan kulit tangan dan kuku terhadap penyakit dermatitis

Berdasarkan tabel 1 dari 45 santriwati yang diteliti, yang memenuhi syarat dari segi kebersihan kulit tangan dan kuku yaitu 8 $(17,8 \%)$ santriwati dan diketahui terkena dermatitis 3 santriwati dan tidak dermatitis 5 santriwati. Sedangkan yang tidak memenuhi syarat dari segi kebersihan kulit tangan dan kuku yaitu $37(82,2 \%)$ santriwati dan diketahui terkena dermatitis 20 santriwati dan tidak dermatitis 17 santriwati. Berdasarkan hasil uji statistik dengan menggunakan uji chi square diperoleh nilai $\mathrm{P}=0,39>\alpha=0,05$ maka $\mathrm{Ha}$ di tolak dan nilai Ho diterima dengan kesimpulan bahwa tidak ada hubungan yang bermakna antara kebersihan kulit, tangan dan kuku terhadap penyakit dermatitis.

Tabel 1

Distribusi Kebersihan Kulit Tangan Dan Kuku pada santriwati Pondok Pesantren Babul Khaer Kab.Bulukumba Tahun 2019

$\begin{array}{llll} & & & \text { Persent } \\ \text { Indikator } & \text { Kriteria } & \mathrm{n} & \text { ase } \\ \text { Penilain } & & \end{array}$

$(\%)$

\begin{tabular}{llll}
\hline $\begin{array}{l}\text { Kebersihan } \\
\text { Kulit,Tangan,D } \\
\text { an Kuku }\end{array}$ & $\begin{array}{l}\text { Memenuhi } \\
\text { Syarat }\end{array}$ & 8 & 18 \\
\cline { 2 - 4 } & $\begin{array}{l}\text { Tidak Memenuhi } \\
\text { Syarat }\end{array}$ & 37 & 82 \\
\hline Total & & 45 & 100
\end{tabular}

\section{Hubungan kebiasaan mandi terhadap penyakit dermatitis}

Berdasarkan tabel 2 dari 45 santriwati yang diteliti, yang memenuhi syarat dari segi kebiasaan mandi yaitu $11(24,4)$ santriwati dan diketahui terkena dermatitis 5 santriwati dan tidak dermatitis 6 santriwati. Sedangkan yang tidak memenuhi syarat dari segi kebiasaan mandi yaitu $34(75,6)$ santriwati dan diketahui terkena dermatitis 18 santriwati dan tidak dermatitis 16 santriwati. Berdasarkan hasil uji statistik dengan menggunakan uji chi square diperoleh nilai $\mathrm{P}=$ $0,66>\alpha=0,05$ maka Ha di tolak dan nilai Ho diterima dengan kesimpulan bahwa tidak ada hubungan yang bermakna antara kebiasaan mandi terhadap penyakit dermatitis.

\section{HASIL}


Jurnal Sulolipu : Media Komunikasi Sivitas Akademika dan Masyarakat

Vol. 20 No.12020

e-issn : 2622-6960, p-issn : 0854-624X

Pesantren Babul Khaer Kab.BulukumbaTahun 2019

Indikator Kersenta
Peniteria

Indikator Kriteria $\quad \mathrm{n}$
Penilain

\begin{tabular}{llcc}
\hline & $\begin{array}{l}\text { Memenuhi } \\
\text { Kebiasaa }\end{array}$ & 11 & 24 \\
\cline { 2 - 4 } n Mandi & $\begin{array}{l}\text { Tidak } \\
\text { Memenuhi } \\
\text { Syarat }\end{array}$ & 34 & 76 \\
\hline Total & & 45 & 100 \\
\hline
\end{tabular}

Sumber : Data primer

Hubungan kebiasaan mengganti pakaian terhadap penyakit dermatitis

Berdasarkan tabel 3 dari 45 santriwati yang diteliti, yang memenuhi syarat dari segi kebiasaan mengganti pakaian yaitu $31(68,9)$ santriwati, dan diketahui terkena dermatitis 12 santriwati dan tidak dermatitis 19 santriwati. Sedangkan yang tidak memenuhi syarat dari segi kebiasaan mengganti pakaian yaitu 14 $(31,1 \%)$, dan diketahui terkena dermatitis 11 santriwati dan tidak dermatitis 3 santriwati. Berdasarkan hasil uji statistik dengan menggunakan uji chi square diperoleh nilai $\mathrm{P}=$ $0,01<\alpha=0,05$ maka Ho di tolak dan nilai $\mathrm{Ha}$ diterima dengan kesimpulan bahwa ada hubungan yang bermakna antara Kebiasaan Mengganti Pakaian terhadap penyakit dermatitis.

Tabel 3

Distribusi Kebiasaan mengganti pakaian pada santriwati Pondok Pesantren Babul Khaer Kab.Bulukumba Tahun 2019

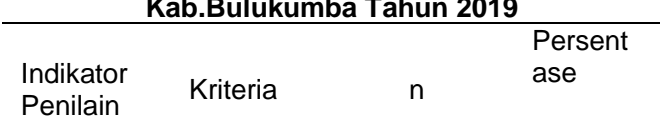

\begin{tabular}{llcc}
\hline Kebiasaa & $\begin{array}{l}\text { Memenuhi } \\
\mathrm{n}\end{array}$ & 31 & 69 \\
\cline { 2 - 4 } $\begin{array}{l}\text { Sengarat } \\
\text { Pakaiant }\end{array}$ & $\begin{array}{l}\text { Tidak } \\
\text { Memenuhi } \\
\text { Syarat }\end{array}$ & 14 & 31 \\
\hline Total & & 45 & 100 \\
\hline
\end{tabular}

Sumber : Data primer

Hubungan kebersihan tempat tidur dan seprei terhadap penyakit dermatitis

Berdasarkan tabel 4 dari 45 santriwati yang diteliti, yang memenuhi syarat dari kebersihan tempat tidur dan seprei yaitu $0(0 \%)$ santriwati sedangkan yang tidak memenuhi syarat dari

segi kebersihan tempat tidur dan seprei yaitu $45(100 \%)$ santriwati dan diketahui terkena dermatitis sebanyak 23 santriwati dan tidak dermatitis 22 santriwati.

Tabel 4

Distribusi Kebersihan tempat tidur dan seprei pada santriwati Pondok Pesantren Babul Khaer Kab.Bulukumba Tahun 2019

$\begin{array}{llll}\begin{array}{l}\text { Indikator } \\ \text { Penilain }\end{array} & \text { Kriteria } & \mathrm{n} & \mathrm{e}^{\text {Persentas }}\end{array}$

(\%)

\begin{tabular}{llll}
\hline Kebersina & Memenuhi & 0 & 0 \\
$\mathrm{n}$ Tempat & Syarat & & \\
\cline { 2 - 4 } $\begin{array}{l}\text { Tidur dan } \\
\text { Seprei }\end{array}$ & $\begin{array}{l}\text { Tidak } \\
\text { Memenuhi } \\
\text { Syarat }\end{array}$ & 45 & 100 \\
\hline
\end{tabular}

\begin{tabular}{lcc}
\hline Total & 45 & 100 \\
\hline Sumber : Data primer & &
\end{tabular}

\section{Hubungan kualitas fisik air terhadap} penyakit dermatitis

Berdasarkan tabel 5 , dari 45 santriwati yang diteliti yang menggunakan air bersih memenuhi syarat secara fisik (Bau, warna dan rasa) yaitu $45(100 \%)$ santriwati dan diketahui 23 terkena dermatitis dan 22 tidak dermatitis. Sedangkan yang menggunakan air bersih tidak memenuhi syarat secara fisik (Bau, warna dan rasa) sebanyak $0(0 \%)$ santriwati.

Tabel 5

Distribusi kualitas fisik air di Pondok Pesantren Babul Khaer Kab.Bulukumba Tahun 2019

Indikator Kriteria Jumlah Persentase

\begin{tabular}{lll} 
Penilain Kriteria Jumlah & \\
& & \\
\hline
\end{tabular}

\begin{tabular}{llll}
\hline & $\begin{array}{l}\text { Memenuhi } \\
\text { Sualitas fisik } \\
\text { air }\end{array}$ & 9 & 100 \\
\cline { 2 - 4 } & $\begin{array}{l}\text { Sidak } \\
\text { Memenuhi } \\
\text { Syarat }\end{array}$ & 0 & 0 \\
\hline Total & & 9 & 100 \\
\hline
\end{tabular}

Sumber : Data primer

Hubungan suhu kamar tidur santriwati terhadap penyakit dermatitis

Berdasarkan tabel 6 , dari 45 santriwati yang diteliti yang memiliki suhu kamar tidur memenuhi syarat sebanyak 21 (46,7\%) dan 
diketahui terkena dermatitis sebanyak 7 santriwati dan tidak terken dermatitis sebanyak 8 santriwati. Sedangkan suhu ruangan kamar tidur yang tidak memenuhi syarat sebanyak $24(53,3 \%)$ dan diketahui terkena dermatitis sebanyak 16 santriwati dan tidak terkena dermatitis sebanyak 8 santriwati. Berdasarkan hasil uji statistik dengan menggunakan uji chi square diperoleh nilai $\mathrm{P}=$ $0,02<\alpha=0,05$ maka Ho di tolak dan nilai $\mathrm{Ha}$ diterima dengan kesimpulan bahwa ada hubungan yang bermakna antara suhu ruangan kamar tidur terhadap penyakit dermatitis.

Tabel 6

Distribusi Suhu kamar tidur santriwati Pondok Pesantren Babul Khaer Kab.Bulukumba Tahun 2019

\begin{tabular}{llllll}
\hline $\begin{array}{l}\text { Indik } \\
\text { ator } \\
\begin{array}{l}\text { Penil } \\
\text { ain }\end{array}\end{array}$ & $\begin{array}{l}\text { Krite } \\
\text { ria }\end{array}$ & $\begin{array}{l}\text { Meme } \\
\text { nuhi } \\
\text { syarat }\end{array}$ & $\begin{array}{l}\text { Persen } \\
\text { tase } \\
\text { (\%) }\end{array}$ & $\begin{array}{l}\text { Tidak } \\
\text { meme } \\
\text { nuhi } \\
\text { syarat }\end{array}$ & $\begin{array}{l}\text { Persen } \\
\text { tase } \\
\text { (\%) }\end{array}$ \\
\hline \multirow{2}{*}{ Suhu } & Pagi & 9 & 100 & 0 & 0 \\
\cline { 2 - 6 } & $\begin{array}{l}\text { Sian } \\
\text { g }\end{array}$ & 4 & 44 & 5 & 56 \\
\cline { 2 - 6 } & Sore & 9 & 100 & 0 & 0 \\
\hline
\end{tabular}

Hubungan kelembaban kamar tidur santriwati terhadap penyakit dermatitis

Berdasarkan tabel 7, dari 45 santriwati yang diteliti yang memiliki kelembaban kamar tidur memenuhi syarat sebanyak $0(0 \%)$ santriwati. Sedangkan yang memiliki kelembaban ruangan kamar tidur tidak memenuhi syarat sebanyak $45(100 \%)$ santriwati, dan diketahui terkena dermatitis 23 santriwati dan tidak dermatitis 22 santriwati.

Tabel 7

Distribusi Kelembaban kamar tidur santriwati Pondok Pesantren Babul Khaer Kab.Bulukumba Tahun 2019

\begin{tabular}{llllll}
\hline $\begin{array}{l}\text { Indikato } \\
r\end{array}$ & $\begin{array}{l}\text { Krit } \\
\text { Penilain }\end{array}$ & $\begin{array}{l}\text { Meme } \\
\text { nuhi } \\
\text { syarat }\end{array}$ & $\begin{array}{l}\text { Persen } \\
\text { tase } \\
(\%)\end{array}$ & $\begin{array}{l}\text { Tidak } \\
\text { meme } \\
\text { nuhi } \\
\text { syarat }\end{array}$ & $\begin{array}{l}\text { Persen } \\
\text { tase } \\
(\%)\end{array}$ \\
\hline & Pagi & 0 & 0 & 9 & 100 \\
\cline { 2 - 6 } $\begin{array}{l}\text { Kelemb } \\
\text { aban }\end{array}$ & $\begin{array}{l}\text { Sian } \\
\mathrm{g}\end{array}$ & 0 & 0 & 9 & 100 \\
& $\begin{array}{l}\text { Sor } \\
\text { e }\end{array}$ & 0 & 0 & 9 & 100
\end{tabular}

Sumber : data primer
Berdasarkan analisa data yang telah dilakukan terhadap 45 responden di pondok pesantren babul khaer kab. Bulukumba maka dikemukakan sebagai berikut :

\section{Hubungan Kebersihan kulit, tangan dan kuku terhadap penyakit dermatitis}

Kebiasaan membersihkan kulit, tangan dan kuku bagi santriwati merupakan hal wajib yang mesti dilakukan agar untuk menjaga dan memelihara kebersihan diri mereka dan terhindar dari beberapa penyakit, khususnya penyakit kulit. Berdasarkan hasil observasi terhadap santriwati di pondok pesantren Babul Khaer Kab.Bulukumba banyak santriwati yang memiliki kuku yang panjang serta kebiasaan negatif santriwati tidak memotong kuku menggunakan alat khusus melainkan hanya menggigit kuku yang dapat memicu terjadinya beberapa penyakit yang bisa timbul akibat kebiasaan buruk tersebut. Selain itu kebiasaan mencuci tangan menggunakan sabun dan air mengalir setelah melakukan aktivitas juga dihiraukan oleh beberapa santriwati.

Hal ini berbanding terbalik dengan hasil yang didapatkan dengan observasi yang dilakukan. Hasil yang didapatkan yaitu tidak ada hubungan antara kebersihan kulit, tangan dan kuku terhadap penyakit dermatitis di Pondok Pesantren Babul Khaer Kab.Bulukumba sedangkan berdasarkan observasi yang dilakukan, santriwati memiliki personal hygiene terutama pada kebersihan kulit tangan dan kuku sangat kurang. Adapun faktor yang menjadi perbedaan antara hasil dan observasi yaitu karena pada saat pengisian kuesioner santriwati cenderung menjawab baik namun kenyataannya hal tersebut tidak sesuai dengan observasi yang dilakuakan.

\section{Hubungan Kebiasaan mandi terhadap penyakit Dermatitis}

Salah satu bagian dari upaya kebersihan diri yang dapat dilakukakan santriwati yaitu memperhatikan kebiasaan mandi. Kebiasaan mandi yang dimaksud dalam penelitian ini adalah mandi 2 kali dalam sehari, menggunakan air bersih, menggunakan sabun, dan menggunakan shampoo minimal 3 kali seminggu. Salah satu faktor yang menjadi pemicu kurangnya upaya memelihara kebersihan diri Santriwati di Pondok Pesantren adalah tidak adanya kesadaran akan pentingnya kesehatan dan kurangnya pengetahuan tentang cara berprilaku hidup bersih dan sehat khususnya dalam upaya 
memelihara kebersihan diri santriwati .

Kebiasaan mandi santriwati sudah memenuhi syarat yaitu 2 kali sehari dengan menggunakan sabun dan air bersih. Akan tetapi sabun yang digunakan yaitu sabun batangan yang kadang dipakai secara bergantian oleh santriwati dan tidak membedakan antara sabun yang digunakan pada saat mandi dan yang digunakan setelah buang air besar.

Selain itu, kebiasaan mengganti handuk ataupun mencuci handuk minimal 1 kali seminggu juga menjadi masalah bagi santriwati di pondok pesantren. Menurut Robert masalah terbesar dengan handuk adalah kelembaban yang konsisten artinya handuk yang dipakai secara berulang atau dalam keadaan lembab dapat mempercepat pertumbuhan bakteri pada handuk tersebut. Maka dari itu, setelah menggunakan handuk langsung dijemur dibawah terik matahari yang dapat menjadi cara untuk menghentikan pertumbuhan bakteri termasuk jamur.

\section{Hubungan Kebiasaan mengganti pakaian terhadap penyakit Dermatitis}

Kesehatan pribadi merupakan hal yang sangat penting bagi seseorang dan untuk memiliki kondisi sehat, hanya pribadi masing - masing yang mampu mengkondisikannya. Berdasarkan tabel 5.10 hasil analisa bivariat Dengan hasil uji statistik dengan menggunakan uji chi square diperoleh nilai $\mathrm{P}=$ $0,01<\alpha=0,05$ maka Ho di tolak dan nilai $\mathrm{Ha}$ diterima dengan kesimpulan bahwa ada hubungan yang bermakna antara Kebiasaan Mengganti Pakaian terhadap penyakit dermatitis.

Hasil penelitian ini sesuai dengan hasil penelitian Muzakir (2008) yang menemukan bahwa terdapat hubungan antara kebersihan diri (mengganti pakaian) dengan kejadian Dermatitis di pondok pesantren Kabupaten Aceh Besar.

Melakukan kebiasaan seperti kebiasaan mengganti pakaian, tidak memakai pakaian yang lembab, memakai pakaian dalam keadaan bersih, memisahkan pakaian bersih dan pakaian kotor, tidak meminjam pakaian teman dapat mengurangi risiko terkena penyakit dermatitis dan kepedulian terhadap kesehatan pribadi santriwati perlu diperhatikan.

\footnotetext{
Hubungan Kebersihan tempat tidur dan seprei terhadap penyakit Dermatitis
}

Kebersihan diri (personal hygiene) sangat berkaitan dengan tempat tidur yang digunakan sehari-hari. Kebersihan tempat tidur bertujuan untuk memutuskan perkembangbiakan bakteri yang dapat timbul akibat kelembaban tempat tidur yang dapat menimbulkan alergi ataupun gatal-gatal pada santriwati. Tempat tidur merupakan salah satu faktor yang menentukan kualitas tidur. Agar kasur tetap bersih dan terhindar dari kuman penyakit maka perlu menjemur kasur $1 \mathrm{x}$ seminggu karena tanpa disadari kasur akan menjadi lembab hal ini dikarenakan seringnya berbaring dan suhu kamar yang berubahrubah (Handri, 2010).

Menurut Lita (2005) kuman penyebab penyakit kulit yang senang hidup dan berkembangbiak di perlengkapan tidur. Dengan menjemur kasur sekali seminggu dan mengganti seprei sekali seminggu ini bisa mengurangi perkembangbiakan kuman penyakit kulit.

\section{Hubungan Kualitas fisik air terhadap penyakit Dermatitis}

Kualitas air secara fisik yaitu meliputi bau, kekeruhan dan rasa. Berdasarkan hasil observasi yang telah dilakukan pada bak penampungan maupun melalui air yang dialirkan melalui kran asrama di Pondok Pesantren Babul Khaer sudah memenuhi syarat secara fisik. Bak penampungan air yang digunakan di Pondok Pesantren Babul Khaer Kab.Bulukumba dibersihkan sekali seminggu oleh petugas kebersihan Pondok Pesantren dan dibantu oleh Santriwati.

Berdasarkan informasi yang didapat dari para santri, tidak ada pernah ada keluhan kualitas air sumur di Pondok Pesantren Babul Khaer Kab.Bulukumba sehingga risiko penyakit kulit bagi santriwati kemungkinan sangat kecil.

\section{Hubungan Suhu kamar tidur terhadap penyakit Dermatitis}

Suhu adalah kandungan uap air yang terdapat didalam ruang yang besar diukur dengan menggunakan thermometer dengan satuan pengukuran derajat celcius $\left({ }^{\circ} \mathrm{C}\right)$. Suhu udara memiliki peranan sangat penting, suhu akan berpengaruh baik langsung maupun tidak langsung terhadap kehidupan manusia. Suhu ruangan, yaitu dalam pembuatan ruangan harus diusahakan agar konstruksinya sedemikian rupa sehingga suhu ruangan tidak berubah banyak dan agar kelembaban udara dapat dijaga jangan sampai terlalu tinggi dan terlalu rendah. Untuk ini harus diusahakan 
Jurnal Sulolipu : Media Komunikasi Sivitas Akademika dan Masyarakat

Vol. 20 No. 12020

e-issn : 2622-6960, p-issn : 0854-624X

agar perbedaan suhu antara dinding, lantai, atap dan permukaan jendela tidak terlalu banyak. Suhu ruangan yang ideal adalah berkisar antara berkisar $18^{\circ} \mathrm{C}-30^{\circ} \mathrm{C}$ ( Permenkes RI, 2011)

Adapun usaha yang dapat dilakukan agar kondisi suhu kamar tidur tetap terjaga yaitu senantiasa membuka ventilasi kamar setiap hari serta bila perlu pengadaan sarana seperti kipas angin untuk meminimalisir suhu kamar yang terlalu tinggi.

\section{Hubungan Kelembaban kamar tidur terhadap penyakit Dermatitis}

Kelembaban ruangan kamar tidur santriwati di Pondok Pesantren Babul khaer berdasarkan pengukuran yang telah dilakukan menggunakan hygrometer semua ruangan kamar tidur tidak ada yang memenuhi syarat atau kelembaban melebihi standar yaitu sesuai dengan Permenkes RI No.1077/Menkes/Per/V/2011 yaitu Memenuhi syarat apabila kelembaban dalam ruang berkisar $40-60 \%$.

Berdasarkan pengukuran yang dilakukan di asrama santriwati pondok pesantren babul khaer kelembaban ruangan kamar tidur tidak ada yang memenuhi syarat karena pada saat dilakukan penelitian dan pengukuran kelembaban, cuaca pada saat itu tidak mendukung (hujan) sehingga mempengaruhi tinnginya kelembaban yang ada dalam ruang kamar tidur santriwati.

\section{KESIMPULAN}

Berdasarkan hasil penelitian yang dilakukan di Pondok Pesantren Babul Khaer Kab.Bulukumba Tahun 2019, maka dapat disimpulkan sebagai berikut :

Ada hubungan yang signifikan antara Kebiasaan Mengganti Pakaian dan suhu kamar tidur santriwati terhadap penyakit dermatitis di Pondok Pesantren Babul Khaer Kab.Bulukumba.

Tidak ada hubungan yang signifikan antara Kebersihan kulit,tangan dan kuku, kebiasaan mandi, kebersihan tempat tidur dan seprei, kualitas fisik air dan kelembaban kamar tidur terhadap penyakit dermatitis di Pondok Pesantren Babul Khaer Kab.Bulukumba.

\section{SARAN}

Menjalin hubungan kerjasama yang berkesinambungan terhadap pengelola pondok pesantren agar dapat meningkatkan pendidikan terutama pemahaman terhadap agama islam agar dapat diterapkan dalam kehidupan bermasyarakat.

Melakukan sosialitasi/penyuluhan terkait Perilaku Hidup Bersih dan Sehat (PHBS), serta membuat kebijakan yang mengatur pengelolaan kesehatan lingkungan dan perilaku santri untuk selalu melakukan personal hygiene. Serta peran ustadz, ustadzah pondok pesantren agar melakukan pengawasan dan turun langsung mengintervensi dalam proses perubahan perilaku personal hygiene santriwati karena para santriwati cenderung lebih patuh pada peraturan Pondok Pesantren.

Santriwati Pondok Pesantren agar berperilaku hidup bersih dan sehat disegala bidang, membiasakan mandi pakai sabun 2 kali sehari serta tidak membiasakan untuk saling meminjam handuk kepada temannya

\section{DAFTAR PUSTAKA} $\begin{gathered}\text { Astutuningsih. } \\ \text { http://akhlinurse.blogspot.co.id/2012/01/Laporan-pendahuluan }\end{gathered}$
Dersonal $\begin{gathered}\text { Hygiene. } \\ \text { Dersonal }\end{gathered}$ Diakses 15 Desember 2018

Balitbangkes. 2007. Laporan Nasional Riset Kesehatan Dasar. Jakarta: Depkes RI

BPS. (2015). Jumlah Kasus Penyakit Menurut Provinsi dan Jenis Penyakit. Makassar : Badan Pusat Statistik Makassar

Damopoli \& Muljono. (2011). Pesantren Modern Immim Pencetak Muslim Modern Edisi 1 cet 1. Jakarta : Kencana Prenada Media Group. 
Jurnal Sulolipu : Media Komunikasi Sivitas Akademika dan Masyarakat

Vol. 20 No.12020

e-issn : 2622-6960, p-issn : 0854-624X

Dani. 2017. Personal Hygiene dan Kejadian Penyakit Kulit pada Penghuni

Rumah Susun

Sederhana Sewa Cokrodirjan Jogjakarta. http://eprints.poltekkesjogia.ac.id/107/

Diakses 8 Desember 2018

Depkes RI. (2010). Profil Kesehatan Indonesia . Jakarta : Depkes RI.

Dinkes Kab.Bulukumba . (2014). Profil Dinas Kesehatan Kabupaten Bulukumba. Bulukumba : Dinas Kesehatan Kabupaten Bulukumba.

Djuanda, a. (2010). Ilmu penyakit kulit dan kelamin. Jakarta : FKUI

Fatma Lestari, Hari Suryo Utomo. 2007 . Faktor-Faktor Yang Berhubungan Dengan Dermatitis Kontak Pada Pekerja di PT. Inti Pantja Press Industri. Fakultas Kesehatan Masyarakat Universitas Indonesia. http://respository.ui.ac.id. Diakses 8 Desember 2018

Isro'in, Laily. \&. (2012). Personal Hygiene, Konsep Proses dan Aplikasi Dalam Praktek Keperawatan. Yogyakarta : Graha Ilmu.

Kementerian Kesehatan. (2007). Laporan Nasional Riset Kesehatan Dasar. Jakarta. Kemenkes $\mathrm{RI}$

Maharani Ayu. (2015). Penyakit Kulit, Perawatan, Pencegahan dan Pengobatan. Yogyakarta : Pustaka Baru Press.

Notoatmodjo Soekidjo. (2007). Perilaku Kesehatan dan Ilmu Perilaku. Jakarta : Rineka Cipta.

Pradananingrum Sinta. DKK. 2018. Hubungan Personal Hygiene, Lama Kontak dan Masa Kerja Dengan Gejala Dermatitis Kontak Iritan Pada Pengrajin Tahu Mrican Semarang. http://ejurnal3.undip.ac.id/index.php/jkm. Diakses 8 desember 2018

Qomar, \& Mujamil. (2007). Pesantren dan Transformasi Metodologi Menuju Demokratisasi Institusi. Jakarta : Erlangga.

Ramlah. (2017). Hubungan Kondisi Ruangan dan Personal Hygiene Terhadap Kejadian Penyakit Kulit Pada Asrama Putri Pondok Pesantren Sultan Hasanuddin Kab.Gowa. Poltekkes Makassar: Jurusan Kesehatan Lingkungan (Penelitian Tidak Dipublikasikan)

Republik Indonesia. 2011. Permenkes RI No. No.1077/menkes/per/v/2011, Pedoman Penyehatan Udara Dalam Ruang Rumah.

Ririn. (2012). Hubungan Perilaku Kebersihan Diri Dengan Kejadian Dermatitis di Puskesmas Cibiru Kota Bandung. http://ejurnal.stikesbhaktikencana.ac.id. Diakses 5 Desember 2018

Sularsito, S. A., \& W.Soebaryo. (2017). Ilmu Penyakit Kulit dan Kelamin. Jakarta : Fakultas Kedokteran Universitas Indonesia.

Tarwoto, \& Wartono. (2006). Kebutuhan Dasar Manusia dan Proses Keperawatan Edisi ke-3. Jakarta: Salemba Medika.

Umiarso, \& Zazin, n. (2011). Pesantren Ditengah Arus Mutu Pendidikan Menjawab Problematika Kontenporer Manajemen Mutu Pesantren. Semarang: Rasail Media. 